\title{
Adhesion and biofilm formation on polystyrene by drinking water-isolated bacteria
}

\author{
Lúcia Chaves Simões • Manuel Simões • \\ Maria João Vieira
}

Received: 3 February 2010/ Accepted: 6 April 2010/Published online: 20 April 2010

(C) Springer Science+Business Media B.V. 2010

\begin{abstract}
This study was performed in order to characterize the relationship between adhesion and biofilm formation abilities of drinking water-isolated bacteria (Acinetobacter calcoaceticus, Burkholderia cepacia, Methylobacterium sp., Mycobacterium тиcogenicum, Sphingomonas capsulata and Staphylococcus sp.). Adhesion was assessed by two distinct methods: thermodynamic prediction of adhesion potential by quantifying hydrophobicity and the free energy of adhesion; and by microtiter plate assays. Biofilms were developed in microtiter plates for 24, 48 and $72 \mathrm{~h}$. Polystyrene (PS) was used as adhesion substratum. The tested bacteria had negative surface charge and were hydrophilic. PS had negative surface charge and was hydrophobic. The free energy of adhesion between the bacteria and PS was $>0 \mathrm{~mJ} / \mathrm{m}^{2}$ (thermodynamic unfavorable adhesion). The thermodynamic approach was inappropriate for modelling adhesion of the tested drinking water bacteria, underestimating adhesion to PS. Only three (B. cepacia, Sph. capsulata and Staphylococcus sp.) of the six bacteria
\end{abstract}

L. C. Simões $(\varangle) \cdot$ M. J. Vieira

IBB-Institute for Biotechnology and Bioengineering, Centre of Biological Engineering, University of Minho, Campus de Gualtar, 4710-057 Braga, Portugal

e-mail: luciachaves@deb.uminho.pt

M. Simões

LEPAE, Department of Chemical Engineering, Faculty of Engineering, University of Porto, Rua Dr. Roberto Frias, s/n, 4200-465 Porto, Portugal were non-adherent to PS. A. calcoaceticus, Methylobacterium sp. and $M$. mucogenicum were weakly adherent. This adhesion ability was correlated with the biofilm formation ability when comparing with the results of $24 \mathrm{~h}$ aged biofilms. Methylobacterium sp. and $M$. mucogenicum formed large biofilm amounts, regardless the biofilm age. Given time, all the bacteria formed biofilms; even those non-adherents produced large amounts of matured ( $72 \mathrm{~h}$ aged) biofilms. The overall results indicate that initial adhesion did not predict the ability of the tested drinking water-isolated bacteria to form a mature biofilm, suggesting that other events such as phenotypic and genetic switching during biofilm development and the production of extracellular polymeric substances (EPS), may play a significant role on biofilm formation and differentiation. This understanding of the relationship between adhesion and biofilm formation is important for the development of control strategies efficient in the early stages of biofilm development.

Keywords Adhesion - Biofilm formation · Hydrophobicity - Opportunistic drinking water bacteria $\cdot$ Surface charge

\section{Introduction}

Many problems in drinking water distribution systems (DWDS) are related with the presence of 
microorganisms, including biofilm growth, nitrification, microbially mediated corrosion, and the occurrence and persistence of pathogens (Regan et al. 2003; Camper 2004; Emtiazi et al. 2004; Bauman et al. 2009). DWDS are known to harbour biofilms, even though these environments are oligotrophic and often contain a disinfectant. By adopting this sessile mode of life, biofilm-embedded microorganisms enjoy a number of advantages over their planktonic counterparts, namely the increased resistance to antimicrobials (Gilbert et al. 2002). Microbial adhesion will initiate biofilm formation, exacerbating contamination of drinking water, reducing the aesthetic quality of potable water, increasing the corrosion rate of pipes and reducing microbiological safety through increased survival of pathogens (Percival and Walker 1999; Niquette et al. 2000). The development of a biofilm is believed to occur in a sequential process that includes transport of microorganisms to surfaces, initial reversible/irreversible adhesion, cellcell communication, formation of microcolonies, extracellular polymeric substances (EPS) production and biofilm maturation (Doyle 2000; Sauer and Camper 2001; Bryers and Ratner 2004; Dobretsov et al. 2009). Accordingly, the adhesion of bacteria to the surface is one of the prime steps in biofilm formation.

Several theoretical approaches have been applied to describe bacteria-surface adhesion, such as the classical Derjaguin-Landau-Verwey-Overbeek (DLVO) theory (Rutter and Vincent 1984; van Loosdrecht et al. 1988, 1990), the extended DLVO (XDLVO) theory (van Oss 1989; Meinders et al. 1995), and the thermodynamic approach (surface Gibbs energy) (Absolom et al. 1983; Busscher et al. 1984). When a microorganism and a surface in aqueous solution enter in direct contact the water film present between the interacting entities has to be removed. This is in accordance with the thermodynamic theory of adhesion and is expressed by the Dupré equation which states that the Gibbs free energy of interaction can be calculated assuming that the interfaces between bacteria/liquid medium and solid/liquid medium are replaced by a bacteria/solid interface (Absolom et al. 1983). The interaction between a microbial cell and a solid substratum is only possible from a thermodynamic point of view if it leads to a decrease in the surface Gibbs free energy (Absolom et al. 1983; Busscher et al. 1984). Those approaches consider bacteria as colloids. However, important biological factors have been largely ignored in those models. Walker et al. (2004, 2005) have found that the heterogeneity of active sites from cell surface macromolecules, such as proteins and lipopolysaccharideassociated functional groups, controls the adhesion process.

Bacterial adhesion is a complex process that is affected by many factors, including the physicochemical characteristics of bacteria (hydrophobicity, surface charge), the material surfaces properties (chemical composition, surface charge, hydrophobicity, roughness and texture) and by the environmental factors (temperature, $\mathrm{pH}$, time of exposure, bacterial concentration, chemical treatment or the presence of antimicrobials and fluid flow conditions). The biological properties of bacteria, such as the presence of fimbriae and flagella, and the production of EPS also influence the attachment to surface (An and Friedman 1998). Recently, adhesion has been described as a two-phase process including an initial, instantaneous, and reversible physicochemical phase and a timedependent and irreversible molecular and cellular phase (Pavithra and Doble 2008). In the first phase, planktonic bacteria move or are moved to a surface through and by the effects of physical forces, such as Brownian motion, van der Waals attraction forces, gravitational forces, the effect of surface electrostatic charge, and hydrophobic interactions. These physical interactions are further classified as long-range (non-specific, distances $>150 \mathrm{~nm}$ ) and short-range interactions (distances $<3 \mathrm{~nm}$ ). Bacteria are first transported to the surface by the long-range interactions and at closer proximity the short-range interactions become more important. In the second phase, molecular reactions between bacterial surface structures and substratum surfaces become predominant. This implies a firmer adhesion of bacteria to a surface by the bridging function of bacterial surface polymeric structures.

The understanding of the overall biofilm formation process depends on the deep understanding of the main aspects regulating biofilm development, such as the initial adhesion. However, there is a lack of information regarding the behavior of cells in the earlier stages of biofilm formation, and its relationship with the biofilm development process. This study was performed in order to characterize the adhesion and biofilm formation abilities of drinking 
water-isolated bacteria to polystyrene (PS) and to assess the possible relationships between adhesion and biofilm results.

\section{Materials and methods}

Bacteria isolation and identification

The microorganisms used throughout this work were isolated from a model laboratory DWDS, as described previously by Simões et al. (2006). Identification tests, by determination of $16 \mathrm{~S}$ rDNA gene sequence, were performed for putative bacteria according to the method described by Simões et al. (2007a).

Planktonic bacterial growth

Assays were performed with 6 representative (above $80 \%$ of the total bacterial genera isolated and identified) drinking water bacteria: Acinetobacter calcoaceticus, Burkholderia cepacia, Methylobacterium sp., Mycobacterium mucogenicum, Sphingomonas capsulata and Staphylococcus sp.

Bacterial cells were grown overnight in batch culture using $100 \mathrm{ml}$ of R2A (Merck, Portugal) broth, at room temperature $\left(23^{\circ} \mathrm{C} \pm 2\right)$, under agitation $(150 \mathrm{rpm})$. Cells were harvested by centrifugation (20 $\mathrm{min}$ at $13,000 \times \mathrm{g}$ ), washed three times in saline phosphate buffer (0.1 M PBS, pH 7.2) and resuspended in a certain volume of sterile tap water $(\mathrm{pH}$ $6.7 \pm 0.2$ ) or R2A broth (biofilm studies) necessary to achieve the bacterial concentration required for each assay.

\section{Substratum}

The material assayed was PS. In order to prepare PS for further analysis, it was immersed in a solution of commercial detergent (Sonasol Pril, Henkel Ibérica S. A.) and ultrapure water for $30 \mathrm{~min}$. In order to remove any remaining detergent, the material was rinsed in ultrapure water and subsequently immersed in ethanol at $96 \%(\mathrm{v} / \mathrm{v})$ for $10 \mathrm{~s}$. After being rinsed three times with ultrapure water, it was dried at $65^{\circ} \mathrm{C}$ for $3 \mathrm{~h}$ before being used for contact angle measurements, zeta potential assessment and adhesion assays.
Zeta potential

Zeta potential experiments were performed with the cells resuspended in sterile tap water at a final concentration of $10^{9}$ cells $/ \mathrm{ml}$. The zeta potential of PS was also assessed. The experiments were determined using a Malvern Zetasizer instrument (Zetasizer Nano ZS ZEN3600, Malvern). Before measuring the electrostatic values, the zeta potential cell (DTS1060, Malvern) was rinsed three times with each suspension using a disposable syringe. All experiments were carried out at room temperature. The zeta potential was derived from the electrophoretic mobility using the Smoluchowski approximation (Hunter 1981). The experiments were performed in triplicate and repeated three times.

Surface contact angles

Bacterial lawns for contact angle measurements were prepared as described by Busscher et al. (1984). The surface tension of the bacterial surfaces and of the adhesion surface were then determined using the sessile drop contact angle method. The measurements were carried out at room temperature $\left(23^{\circ} \mathrm{C} \pm 2\right)$ using three different liquids: water, formamide and $\alpha$-bromonaphtalene (Sigma, Portugal). Determination of contact angles was performed automatically using a model OCA 15 Plus (DATAPHYSICS, Germany) video based optical contact angle measure instrument, allowing image acquisition and data analysis.

Contact angle measurements (at least 25 determinations for each liquid and for each microorganism and PS) were performed at three independent experiments for each condition tested. The reference liquids surface tension components were obtained from literature (Janczuk et al. 1993).

Surface hydrophobicity and free energy of adhesion

Hydrophobicity was assessed after contact angle measurements and using the approach of van Oss et al. (1987, 1988, 1989). In this approach, the degree of hydrophobicity of a given material (1) is expressed as the free energy of interaction between two entities of that material when immersed in water (w) $\Delta \mathrm{G}_{1 \mathrm{w} 1}$. If the interaction between the two entities is stronger than the interaction of each entity with water 
$\Delta \mathrm{G}_{1 \mathrm{w} 1}<0 \mathrm{~mJ} / \mathrm{m}^{2}$ the material is considered hydrophobic. Conversely, if $\Delta \mathrm{G}_{1 \mathrm{w} 1}>0 \mathrm{~mJ} / \mathrm{m}^{2}$ the material is hydrophilic. $\Delta \mathrm{G}_{1 \mathrm{w} 1}$ can be calculated through the surface tension components of the interacting entities, according to:

$$
\begin{aligned}
\Delta \mathrm{G}_{1 \mathrm{w} 1}= & -2\left(\sqrt{\gamma_{1}^{\mathrm{LW}}}-\sqrt{\gamma_{\mathrm{w}}^{\mathrm{LW}}}\right)^{2} \\
& +4\left(\sqrt{\gamma_{1}^{+} \gamma_{\mathrm{w}}^{-}}+\sqrt{\gamma_{1}^{-} \gamma_{\mathrm{w}}^{+}}-\sqrt{\gamma_{1}^{+} \gamma_{1}^{-}}-\sqrt{\gamma_{\mathrm{w}}^{+} \gamma_{\mathrm{w}}^{-}}\right)
\end{aligned}
$$

where $\gamma^{\mathrm{LW}}$ accounts for the Lifshitz-van der Waals component of the surface free energy and $\gamma^{+}$and $\gamma-$ are the electron acceptor and electron donor parameters, respectively, of the Lewis acid-base component $\left(\gamma^{\mathrm{AB}}\right)$, with $\gamma^{\mathrm{AB}}=2 \times \sqrt{\gamma^{+} \gamma^{-}}$.

The surface tension components of a surface (s) (bacteria or substratum) are obtained by measuring the contact angles of three pure liquids (1) (one apolar- $\alpha$-bromonaphtalene and two polar-water and formamide), with well known surface tension components, followed by the simultaneous resolution of three equations of the form:

$$
(1+\cos \theta) \gamma_{1}^{\mathrm{TOT}}=2\left(\sqrt{\gamma_{\mathrm{s}}^{\mathrm{LW}} \gamma_{1}^{\mathrm{LW}}}+\sqrt{\gamma_{\mathrm{s}}^{+} \gamma_{1}^{-}}+\sqrt{\gamma_{\mathrm{s}}^{-} \gamma_{1}^{+}}\right)
$$

where $\theta$ is the contact angle and $\gamma^{\mathrm{TOT}}=\gamma^{\mathrm{LW}}+\gamma^{\mathrm{AB}}$.

The free energy of adhesion was calculated through the surface tension components of the entities involved in the adhesion process by the thermodynamic theory expressed by Dupré equation (3). When studying the interaction between one bacteria (b) and a substratum (s) that are immersed or dissolved in water (w), the total interaction energy, $\Delta \mathrm{G}_{\mathrm{bws}}^{\mathrm{TOT}}$, can be expressed by the interfacial tensions components as:

$\Delta \mathrm{G}_{\mathrm{bws}}^{\mathrm{TOT}}=\gamma_{\mathrm{bs}}-\gamma_{\mathrm{bw}}-\gamma_{\mathrm{sw}}$

For instance, the interfacial tension for one diphasic system of interaction (bacteria/substratum- $\gamma_{\text {bs }}$ ) can be defined by the thermodynamic theory according to the following equations:

$$
\begin{aligned}
& \gamma_{\mathrm{bs}}=\gamma_{\mathrm{bs}}^{\mathrm{LW}}+\gamma_{\mathrm{bs}}^{\mathrm{AB}} \\
& \gamma_{\mathrm{bs}}^{\mathrm{LW}}=\gamma_{\mathrm{b}}^{\mathrm{LW}}+\gamma_{\mathrm{s}}^{\mathrm{LW}}-2 \times \sqrt{\gamma_{\mathrm{b}}^{\mathrm{LW}} \times \gamma_{\mathrm{s}}^{\mathrm{LW}}}
\end{aligned}
$$

$$
\begin{aligned}
\gamma_{\mathrm{bs}}^{\mathrm{AB}=} & 2 \times\left(\sqrt{\gamma_{\mathrm{b}}^{+} \times \gamma_{\mathrm{b}}^{-}}+\sqrt{\gamma_{\mathrm{s}}^{+} \times \gamma_{\mathrm{s}}^{-}}\right. \\
& \left.-\sqrt{\gamma_{\mathrm{b}}^{+} \times \gamma_{\mathrm{s}}^{-}}-\sqrt{\gamma_{\mathrm{b}}^{-} \times \gamma_{\mathrm{s}}^{+}}\right)
\end{aligned}
$$

The other interfacial tension components, $\gamma_{b w}$ (bacteria/water) and $\gamma_{\mathrm{sw}}$ (substratum/water), were calculated in the same way. The value of the free energy of adhesion was obtained by the application of Eqs. 3-6, which allowed the assessment of thermodynamic adhesion. Thermodynamically, if $\Delta \mathrm{G}_{\mathrm{bws}}^{\mathrm{TOT}}<0 \mathrm{~mJ} / \mathrm{m}^{2}$ the adhesion of one bacteria to substratum is favourable. On the contrary, adhesion is not expected to occur if $\Delta \mathrm{G}_{\mathrm{bws}}^{\mathrm{TOT}}>0 \mathrm{~mJ} / \mathrm{m}^{2}$.

\section{Adhesion}

Coupons of PS with $8 \mathrm{~mm} \times 8 \mathrm{~mm}$, prepared as indicated previously, were inserted in the bottom of 24-wells (15 mm diameter each well) microtiter plates (polystyrene, Orange Scientific, USA) and $2 \mathrm{ml}$ of each cell suspension $\left(10^{9}\right.$ cells $/ \mathrm{ml}$ in sterile tap water), was added to each well. Adhesion to each material was allowed to occur for $2 \mathrm{~h}$ at room temperature, in an orbital shaker at $150 \mathrm{rpm}$, according to the methods of Simões et al. (2007a). Negative controls were obtained by placing PS in sterile tap water without bacterial cells. At the end of the assay each well was washed twice with sterile distilled water, by pipetting carefully only the liquid above the coupon to remove reversibly adherent bacteria. After the last wash, the coupons were used for biomass quantification by crystal violet (CV) staining. All the experiments were performed in triplicate with three repeats.

\section{Biofilm formation}

Biofilms were developed according to the modified microtiter plate test proposed by Stepanović et al. (2000). Briefly, for each bacterium at least sixteen wells of a sterile 96-well flat tissue culture plates (polystyrene, Orange Scientific, USA) were filled under aseptic conditions with $200 \mu \mathrm{l}$ of cell suspension $\left(1 \times 10^{8}\right.$ cells $/ \mathrm{ml}$ in $\mathrm{R} 2 \mathrm{~A}$ broth $)$. To promote biofilm formation, the plates were incubated aerobically on a shaker at $150 \mathrm{rpm}$, at room temperature, 
for 24,48 and $72 \mathrm{~h}$. Each $24 \mathrm{~h}$ the growth medium was carefully discarded and replaced by fresh one. After each biofilm formation period, the content of each well was removed and the wells were washed three times with $250 \mu \mathrm{l}$ of sterile distilled water to remove reversibly adherent bacteria. The plates were air dried for $30 \mathrm{~min}$, and the remaining attached bacteria were analysed in terms of biomass adhered on the surfaces of the microtiter plates. Negative controls were obtained by incubating the wells only with R2A broth without adding any bacterial cells. All the experiments were repeated three times.

\section{Biomass quantification by $\mathrm{CV}$}

The coupons with adhered bacteria in the 24-wells plates were removed from each well and immersed in a new microtiter plate containing $1 \mathrm{ml}$ of methanol $98 \%(\mathrm{v} / \mathrm{v})$ in each well for biomass quantification by crystal violet (CV-Gram colour-staining set for microscopy, Merck) (Simões et al. 2007a). Methanol was withdrawn after $15 \mathrm{~min}$ of contact and the coupons were allowed to dry at room temperature. Aliquots $(600 \mu \mathrm{l})$ of $\mathrm{CV}$ were then added to each well and incubated for $5 \mathrm{~min}$. After gently washing in water the coupons were left to dry, before being immersed in $1 \mathrm{ml}$ of acetic acid 33\% (v/v) to release and dissolve the stain.

The bacterial biofilms in the 96-wells plates were fixed with $250 \mu \mathrm{l}$ of $98 \%$ methanol (Vaz Pereira, Portugal) per well for $15 \mathrm{~min}$. Afterwards, the plates were emptied and left to dry. Then, the fixed bacteria were stained for 5 min with $200 \mu \mathrm{l}$ of CV per well. Excess stain was rinsed off by placing the plate under running tap water (Stepanović et al. 2000). After the plates were air dried, the dye bound to the adherent cells was resolubilized with $200 \mu \mathrm{l}$ of $33 \%$ (v/v) glacial acetic acid (Merck, Portugal) per well.

The optical density (OD) of the obtained solutions were measured at $570 \mathrm{~nm}$ using a microtiter plates reader (BIO-TEK, Model Synergy HT) and adhesion and biofilm mass were presented as $\mathrm{OD}_{570} \mathrm{~nm}$ values.

Adherent/biofilm bacteria classification

Bacteria were classified using the scheme of Stepanović et al. (2000) as follow: non-adherent/nonbiofilm producer (0): OD $\leq$ ODc; weakly adherent/ weak biofilm producer $(+)$ : ODc $<$ OD $\leq 2 \times$ ODc; moderately adherent/moderate biofilm producer $(++): 2 \times$ ODc $<$ OD $\leq 4 \times$ ODc; strongly adherent/strong biofilm producer $(+++): 4 \times$ ODc $<$ OD. This classification was based upon the cut-off of the optical density (ODc) value defined as three standard deviation values above the mean OD of the negative control.

\section{Statistical analysis}

The data were analysed using the statistical program SPSS version 14.0 (Statistical Package for the Social Sciences). Because low samples numbers contributed to uneven variation, the adhesion results were analyzed by the nonparametric Wilcoxon test. Statistical calculations were based on a confidence level $\geq 95 \%$ $(P<0.05$ was considered statistically significant $)$.

\section{Results}

Surface physicochemical properties and free energy of adhesion

Bacterial adhesion can be influenced by the surface physicochemical properties of both bacteria and substratum. Consequently, the drinking water-isolated bacteria and the PS surface were characterized in terms of surface properties-hydrophobicity and surface charge (zeta potential). All the tested isolates had negative zeta potential. The bacteria with the highest zeta potential was $A$. calcoaceticus $(-6.7 \pm 0.4 \mathrm{mV})$ and $M$. mucogenicum $(-31 \pm 3 \mathrm{mV})$ had the lowest zeta potential (Table 1). PS surface had a zeta potential of $-32 \pm 2 \mathrm{mV}$ (Table 1).

The surface hydrophobicity was determined as a quantitative result using the approach proposed by van Oss (1995, 1997), which allows the assessment of the absolute degree of hydrophobicity of any surface in comparison with their interaction with water. Based on this approach the surfaces of the tested bacteria are hydrophilic $\left(\Delta \mathrm{G}_{\mathrm{bwb}}^{\mathrm{TOT}}>0 \mathrm{~mJ} / \mathrm{m}^{2}\right)$ (Table 2). Conversely, the PS surface is hydrophobic $\left(\Delta \mathrm{G}_{\mathrm{sws}}^{\mathrm{TOT}}=-44 \mathrm{~mJ} / \mathrm{m}^{2}\right)$ (Table 2$)$. Bacteria had similar hydrophobicity values $(P>0.05)$, with the exception of Sph. capsulata. According to the surface tension parameters (Table 2), the Lifshitz-van der Waals $\left(\gamma^{\mathrm{LW}}\right)$ component of the bacteria had similar values and all the bacteria were predominantly 
Table 1 Zeta potential $(\mathrm{mV})$ values of drinking water-isolated bacteria and PS

\begin{tabular}{ll}
\hline Zeta potential $(\mathrm{mV})$ & \\
\hline Bacteria & \\
Acinetobacter calcoaceticus & $-6.7 \pm 0.4$ \\
Burkholderia cepacia & $-7.7 \pm 0.3$ \\
Methylobacterium sp. & $-9.0 \pm 0.5$ \\
Mycobacterium mucogenicum & $-31 \pm 3$ \\
Sphingomonas capsulata & $-27 \pm 0.6$ \\
Staphylococcus sp. & $-10 \pm 0.3$ \\
Substratum & $-32 \pm 2$ \\
PS & \\
\hline
\end{tabular}

Values are means \pm SDs of three independent experiments

electron donors $\left(\gamma^{-}\right)$. Moreover, all the bacteria had the ability to accept electrons $\left(\gamma^{+}\right)$. On the other hand, PS had only an electron donating character $\left(\gamma^{+}=0 \mathrm{~mJ} / \mathrm{m}^{2}\right)$.

In order to predict the ability of the microorganisms to adhere to PS surfaces, the free energy of interaction between the bacteria and the surface, when immersed in water, was calculated according to the thermodynamic approach. Based on this approach, all the bacteria had no theoretical thermodynamic ability to adhere to $\mathrm{PS}\left(\Delta \mathrm{G}_{\mathrm{bws}}^{\mathrm{TOT}}>0 \mathrm{~mJ} / \mathrm{m}^{2}\right)$. B. cepacia, had the smallest $\Delta \mathrm{G}_{\mathrm{bws}}^{\mathrm{TOT}}$ and $S p h$. capsulata had the highest $\Delta \mathrm{G}_{\mathrm{bws}}^{\mathrm{TOT}}$ (less prone to adhere to PS).

Table 2 Contact angles (in degrees) with water $\left(\theta_{\mathrm{W}}\right)$, formamide $\left(\theta_{\mathrm{F}}\right), \alpha$-bromonaphtalene $\left(\theta_{\mathrm{B}}\right)$, surface tension parameters, free energy of interaction $\left(\Delta \mathrm{G}_{\mathrm{bwb}}^{\mathrm{TOT}}\right.$ or $\left.\Delta \mathrm{G}_{\mathrm{sws}}^{\mathrm{TOT}}\right)$ of the bacteria (b) and PS (s) when immersed in water (w); free
Adhesion

Adhesion assays were performed with the drinking water-isolated bacteria and PS surfaces, using a modified microtiter-plate assay methodology (Stepanović et al. 2000) and CV staining for biomass assessment of the adhered bacteria. The tested bacteria adhered to PS surfaces (Fig. 1) with different potentials $(P<0.05)$. A. calcoaceticus and Sph. capsulata had the highest and lowest adhesion ability, respectively. Methylobacterium sp. and M. mucogenicum adhered to similar extents $(P>0.05)$. The degree of bacterial adhesion was found to follow the sequence $A$. calcoaceticus $>$ Methylobacterium sp. $>$ M. mucogenicum $>$ Staphylococcus sp. $>B$. cepacia $>$ Sph. capsulata. However, only A. calcoaceticus, Methylobacterium sp. and M. mucogenicum were weakly adherent to PS. The remaining bacteria were classified as non-adherent (Table 3).

\section{Biofilm formation}

In order to assess the biofilm formation ability of the several drinking water-isolated bacteria, a standard 96-wells microtiter plates with CV staining was used to characterize biofilms (Fig. 2). The tested bacteria formed biofilms, with Methylobacterium sp. producing the highest biomass amount for all the sampling times. M. mucogenicum was the second stronger

energy of adhesion $\left(\Delta \mathrm{G}_{\mathrm{bws}}^{\mathrm{TOT}}\right)$ between the bacteria (b) and PS (s) when immersed in water (w). Values are means \pm SDs of three independent experiments

\begin{tabular}{|c|c|c|c|c|c|c|c|c|}
\hline & \multicolumn{3}{|c|}{ Contact angle $\left(^{\circ}\right)$} & \multicolumn{3}{|c|}{$\begin{array}{l}\text { Surface tension } \\
\text { parameters }\left(\mathrm{mJ} / \mathrm{m}^{2}\right)\end{array}$} & \multirow{2}{*}{$\begin{array}{l}\text { Hydrophobicity } \\
\left(\mathrm{mJ} / \mathrm{m}^{2}\right) \\
\Delta \mathrm{G}_{\mathrm{bwb}}^{\mathrm{TOT}} \text { or } \Delta \mathrm{G}_{\mathrm{sws}}^{\mathrm{TOT}}\end{array}$} & \multirow{2}{*}{$\begin{array}{l}\text { Free energy } \\
\text { of adhesion } \\
\left(\mathrm{mJ} / \mathrm{m}^{2}\right) \\
\Delta \mathrm{G}_{\mathrm{bws}}^{\mathrm{TOT}}\end{array}$} \\
\hline & $\theta_{\mathrm{W}}$ & $\theta_{\mathrm{F}}$ & $\theta_{\mathrm{B}}$ & $\gamma^{\mathrm{LW}}$ & $\gamma^{+}$ & $\gamma^{-}$ & & \\
\hline \multicolumn{9}{|l|}{ Bacteria } \\
\hline Acinetobacter calcoaceticus & $28 \pm 1$ & $31 \pm 1$ & $43 \pm 0.8$ & 33 & 1.3 & 51 & 30 & 2.3 \\
\hline Burkholderia cepacia & $38 \pm 2$ & $43 \pm 2$ & $47 \pm 1$ & 32 & 0.5 & 49 & 32 & 0.3 \\
\hline Methylobacterium sp. & $20 \pm 1$ & $20 \pm 2$ & $42 \pm 2$ & 34 & 2.1 & 51 & 28 & 4.1 \\
\hline Mycobacterium mисоgenicum & $27 \pm 1$ & $25 \pm 1$ & $58 \pm 8$ & 26 & 4.4 & 46 & 20 & 5.3 \\
\hline Sphingomonas capsulata & $31 \pm 5$ & $53 \pm 2$ & $73 \pm 4$ & 19 & 1.2 & 69 & 51 & 19 \\
\hline Staphylococcus sp. & $28 \pm 0.9$ & $27 \pm 1$ & $51 \pm 2$ & 30 & 2.8 & 47 & 23 & 3.0 \\
\hline \multicolumn{9}{|l|}{ Substratum } \\
\hline PS & $83 \pm 3$ & $71 \pm 2$ & $28 \pm 1$ & 39 & 0.0 & 9.9 & -44 & - \\
\hline
\end{tabular}


biofilm producer. A directly proportional timebiomass formation was found for the various bacteria $(P<0.05)$, except for B. cepacia $(P>0.05)$. Only for sampling times higher than $48 \mathrm{~h}, \mathrm{Sph}$. capsulata formed biofilms. The degree of biofilm formation was found to follow the sequence-24 h biofilms: Methylobacterium sp. $>$ M. mucogenicum $>$ A. calcoaceticus $>$ Staphylococcus $\quad$ sp. $>$ B. $\quad$ cepacia $>$ Sph. capsulata; $48 \mathrm{~h}$ biofilms: Methylobacterium sp. $>$ M. mucogenicum $>$ B. cepacia $>$ Staphylococcus $\mathrm{sp} .>$ A. calcoaceticus $>$ Sph. capsulata; $72 \mathrm{~h}$ biofilms: Methylobacterium sp. $>$ M. mucogenicum $>$ A. calcoaceticus $>$ Staphylococcus sp. $>$ Sph. capsulata $>$ B. cepacia.

According to the rank of biofilm formation (Table 3), Methylobacterium sp. and M. mucogenicum showed a strong biofilm producing ability for the several sampling times. Sph. capsulata and Staphylococcus sp. only presented biofilm formation ability (moderate) for the $72 \mathrm{~h}$ sampling time. B. cepacia formed weak biofilms after $48 \mathrm{~h}$, while A. calcoaceticus showed variability in the biofilm formation ability by forming weak biofilms at $24 \mathrm{~h}$, being classified as non-biofilm producer at $48 \mathrm{~h}$, and as a strong biofilm producer at the $72 \mathrm{~h}$ sampling time.

\section{Discussion}

The dynamics of the microbial growth and biofilm formation in drinking water networks is very complex, as a large number of interacting processes are
Table 3 Adhesion and biofilm formation ability of drinking water-isolated bacteria to PS according to the classification proposed by Stepanović et al. (2000) and used by Simões et al. (2007b)

\begin{tabular}{|c|c|c|c|c|}
\hline \multirow[t]{2}{*}{ Bacteria } & \multirow[t]{2}{*}{ Adhesion } & \multicolumn{3}{|c|}{ Biofilm } \\
\hline & & $24 \mathrm{~h}$ & $48 \mathrm{~h}$ & $72 \mathrm{~h}$ \\
\hline Acinetobacter calcoaceticus & + & + & 0 & +++ \\
\hline Burkholderia cepacia & 0 & 0 & + & + \\
\hline Methylobacterium sp. & + & +++ & +++ & +++ \\
\hline $\begin{array}{r}\text { Mycobacterium } \\
\text { mucogenicum }\end{array}$ & + & +++ & +++ & +++ \\
\hline Sphingomonas capsulata & 0 & 0 & 0 & ++ \\
\hline Staphylococcus sp. & 0 & 0 & 0 & ++ \\
\hline
\end{tabular}

(0) non-adherent/non-biofilm producer; $(+)$ weakly adherent/ weak biofilm producer; $(++)$ moderately adherent/moderate biofilm producer; $(+++)$ strongly adherent/strong biofilm producer

involved (Simões et al. 2007b, 2008b; Liu et al. 2009). Biofilms are suspected to be the primary source of microorganisms in DWDS that are fed with treated water and have no pipeline breaches, and are of particular concern in older DWDS (LeChevalier et al. 1987). Bacterial adhesion to surfaces, the first step in the formation of a biofilm, has been studied extensively over the past decades in many diverse areas. However, to our knowledge this is the first study reporting the relationship between adhesion and biofilm formation by autochthonous drinking water bacteria. Microorganisms isolated from any given niche, whether medical, environmental, water, or industrial, will have different mechanisms of
Fig. 1 Values of $\mathrm{OD}_{570 \mathrm{~nm}}$ as a measure of bacteria adhesion to PS during $2 \mathrm{~h}$. The means \pm SDs for three independent experiments are illustrated

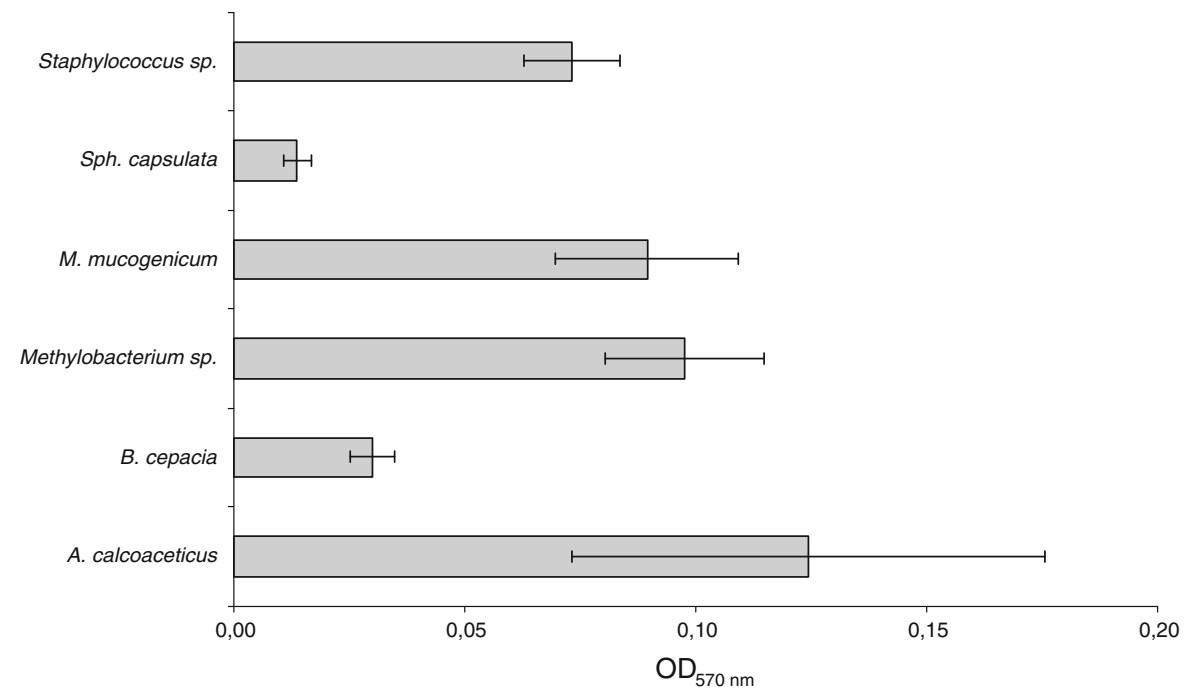


Fig. 2 Values of $\mathrm{OD}_{570 \mathrm{~nm}}$ as a measure of mass of $24 \mathrm{~h}(\square), 48 \mathrm{~h} \mathrm{( \square )} \mathrm{and} 72 \mathrm{~h}$ (ם) aged biofilms. The means \pm SDs for three independent experiments are illustrated

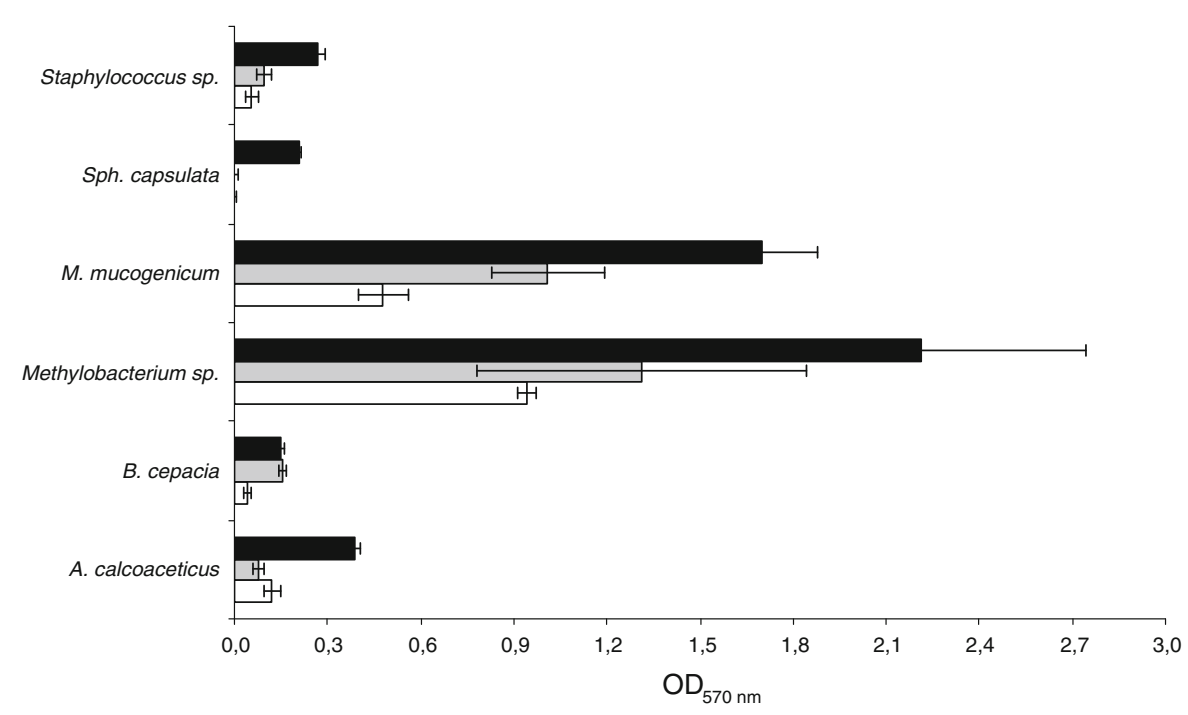

adhesion and retention, not only because the substrata, nutrients, ionic strength, $\mathrm{pH}$ values, and temperatures differ, but also because their phenotype and genotype (expression of structural components and adhesive surface proteins) have adapted differently over time through selective pressures (Thomas et al. 2002). Bakker et al. (2004) also reported that bacterial strains isolated from different niches can exhibit different patterns of adhesion to substrata. The bacteria used in this study are recognized as problematic opportunistic bacteria with the potential to cause public health problems (Bifulco et al. 1989; Rusin et al. 1997; Szewzyk et al. 2000; Zanetti et al. 2000; Conway et al. 2002; Pavlov et al. 2004; Stelma et al. 2004). Similarly to other studies, PS was used as a model surface for adhesion and biofilm formation under laboratorial conditions (Simões et al. 2007b; Pompilio et al. 2008; Silva et al. 2008; Johansen et al. 2009). The PS microtiter plates are commonly used as the standard bioreactor system for adhesion and biofilm formation of bacteria isolated from many different environments, providing reliable comparative data (Djordjevic et al. 2002; Andersson et al. 2008; Cotter et al. 2009). PS has physico-chemical surface properties (hydrophobicity) similar to those of other materials used in water distribution systems such as stainless steel and polyvinylchloride (Simões et al. 2007a). Understanding the relationship between adhesion and biofilm formation is crucial to understand the role microorganisms may play in the system and to develop reliable preventive and control strategies efficient in the early stages of biofilm development.
The influence of the surface free energies of the substratum and the bacterium can be modelled using a thermodynamic approach (Bos et al. 1999). The XDLVO theory accounts for Lifshitz-Van der Waals, electrostatic, and short range acid-base interaction energies between the surface and the bacterium as a function of their separation distance (Van Oss et al. 1986). This mechanistic knowledge of bacterial adhesion obtained from the XDLVO theory provides guidelines for the development of surface coatings exhibiting propensity for minimal bacterial adhesion (Genzer and Efimenko 2006; Webster et al. 2007; Bennett et al. 2010). However, the initial microbial adhesion, as governed by physicochemical interaction forces, is only one of the steps in the development of a mature biofilm. After adsorption of conditioning film components and adhesion of initial colonizers, many subsequent biological, ecological and environmental events determine the ultimate microbial composition and structure of a mature biofilm (Bryers and Ratner 2004; Simões et al. 2009).

Bacterial characteristics known to influence adhesion are hydrophobicity, surface charge, motility, and release of extracellular substances, such as polysaccharides, proteins and metabolite molecules (Dufrene et al. 1996; Kogure et al. 1998; Azeredo et al. 1999; Bos et al. 1999; van Hoogmoed et al. 2000). Relevant properties of the substratum surface are hydrophobicity, charge, and texture (Holland et al. 1998; Bos et al. 1999; Gottenbos et al. 1999; Akesso et al. 2009). Based on the surface properties studied all the bacteria had negative zeta potential and are 
hydrophilic. According to Rijnaarts et al. (1999), at physiological $\mathrm{pH}(\mathrm{pH}$ 7) bacterial cells generally have a net negative charge on their cell wall. In this study, the bacteria had similar hydrophobicity (exception-Sph. capsulata) and zeta potential (exceptions-M. mucogenicum and Sph. capsulata) values. It is not surprising that the surface properties of $M$. mисоgenicum were considerably different from the other bacteria due to the presence of a waxy cell wall. PS had also negative zeta potential, but had a hydrophobic character. Furthermore, it was observed that all bacteria were predominantly electron donors, with low electron acceptor parameters. This polar character can be due to the presence of residual water of hydration or polar groups (van Oss 1994).

A comparison between the theoretical thermodynamic adhesion evaluation and the adhesion assays shows that adhesion was underestimated when based on thermodynamic approaches. In fact, no agreement between thermodynamic approaches and the adhesion assays were obtained for the tested bacteria. Even if for all the bacteria $\Delta \mathrm{G}_{\mathrm{bws}}^{\mathrm{TOT}}>0 \mathrm{~mJ} / \mathrm{m}^{2}$ they adhered to PS. The lack of agreement between thermodynamic and adhesion results proposes that bacterial adhesion on PS surfaces is not influenced by the surface physicochemical properties. Sph. capsulata physicochemical properties revealed the highest hydrophilicity, consequently, being the less prone to adhere to PS according to the thermodynamic approach. This bacterium had also the lowest ability to adhere to PS according to the adhesion assays. This demonstrates that the physicochemical properties account apparently for the low adhesion ability of Sph. capsulata. However, for the other bacteria, no correlation was found between cell surface hydrophobicity and their ability to adhere to PS. This fact is corroborated by other studies (Oliveira et al. 2007; Sousa et al. 2009), likely due to the multiplicity of parameters involved in the adhesion process being influenced both by biological and environmental factors. Also, it is perceptible that the zeta potential differences do not influence the adhesion process. PS, M. mucogenicum and Sph. capsulata had highly negatively charged surfaces (zeta potential < $-25 \mathrm{mV}$ ), while the other bacteria had surfaces with moderate negatively charged. However, there is no clear relationship between the zeta potential data and adhesion. Flint et al. (1997) were unable to assess any relationship between the numbers of Streptococci cells attaching to stainless steel and cell surface charge. Previous studies already reported the lack of a correlation between the bacterial surface properties and attachment. The attachment process was strongly influenced by the presence of extracellular biological molecules ( $\mathrm{Li}$ and Logan 2004; Chae et al. 2006). Barton et al. (1996), however, found that surface growth of Pseudomonas aeruginosa on diverse polymers correlated with the free energy of adhesion, while no such correlation was found for Staphylococcus epidermidis and Escherichia coli. Simões et al. (2008b) found a correlation between the thermodynamic approaches and biofilm formation of a Bacillus cereus strain forming biofilms with low EPS content. In the current study, the lack of agreement between thermodynamic approaches and adhesion assays reinforces that biological mechanisms, such as the expression of extracellular appendages - adhesins that mediate specific interactions with substrata at a nanometer scale, during the irreversible phase of microbial adhesion, in addition to the physicochemical ones, are the plausible aspects mediating the entire adhesion process (Flint et al. 1997; Doyle 2000; Sinde and Carballo 2000; Donlan 2002; Rodrigues and Elimelech 2009).

The importance of initial events in biofilm development still remains unknown due to the multitude of subsequent events taking place on a much longer time scale (Busscher and van der Mei 1997). There are some evidences indicating initial adhesion may be an important aspect in final biofilm formation, particularly for systems under fluctuating shear conditions (Quirynen et al. 1993; Busscher and Van der Mei 1997). Drinking water distributing systems are usually subjected to variable hydraulic situations, ranging from no-flow (stagnant water) to steady-state hydrodynamic conditions. In this study, the magnitude of the initial bacterial adhesion on the subsequent biofilm formation was compared for the drinking water-isolated bacteria (under constant shear conditions) being found that only for Methylobacterium $\mathrm{sp}$. and $M$. mucogenicum, both weakly adherent bacteria, are good biofilm producers regardless the biofilm age. Also, adhesion and biofilm formation are correlated when analyzing the $24 \mathrm{~h}$ aged biofilms. Non-adherent bacteria (B. cepacia, Sph. capsulata and Staphylococcus sp.) are non-biofilm producers or produce low biofilm amounts only for low aged biofilms ( 24 or 48 h). However, after a certain period 
of time all the bacteria had the ability to develop biofilms. When increasing the biofilm formation period the relationship between adhesion and biofilm formation decreases. This time-dependent effects are evident when characterizing the A. calcoaceticus biofilms. This bacterium develops weak biofilms for a $24 \mathrm{~h}$ period, $24 \mathrm{~h}$ later ( $48 \mathrm{~h}$ aged biofilms) the biofilm formation ability decreases and $24 \mathrm{~h}(72 \mathrm{~h}$ aged biofilms) after the bacteria forms large biofilm amounts. This result indicates that the biofilm maturation process increases the system complexity and decreases the possibility of making reliable correlations with the early biofilm development stages. A recent report demonstrated the autoaggregation ability of A. calcoaceticus (Simões et al. 2008a). This bacterial ability provides an increased opportunity for metabolic cooperation in the early biofilm development process, being important not only for colonization, but also for biofilm development (Rickard et al. 2003, 2004). Some authors (Fox et al. 1990; Petrozzi et al. 1993) already questioned the significance of the effect of the initial bacterial adhesion on biofilm formation because the number of bacterial cells involved in the initial biofilm formation process is much smaller than that in mature biofilms. However, other researchers have suggested that there is a link between the initially adhering bacteria and the biofilms that subsequently are formed (Busscher et al. 1995). Motility is another important cellular aspect in the early stages of biofilm formation and development. Pratt and Kolter (1998) demonstrated that surface motility is an important factor in the initial interaction with an abiotic surface. Also, Kogure et al. (1998) have shown that motility increases adhesion to a bare glass substratum. This has been attributed to the increased collision frequency with the solid surface (Morisaki et al. 1999). Comparing the current results with a previous study, it is evident that the motility of the tested drinking water isolates does not regulate adhesion and biofilm formation (Simões et al. 2007b). $B$. cepacia has the highest motility, however, this bacterium is non-adherent and non- $(24 \mathrm{~h})$ or low biofilm producer (48 and $72 \mathrm{~h}$ ). The remaining species had low motility values and similar between then (Simões et al. 2007b). Roosjen et al. (2006) observed that the motility and zeta potential were not distinctive for adhesive and non-adhesive strains, and could therefore not be the reason for the difference in adhesion behavior. In other study, no correlation between motility, adhesion and biofilm formation was found (Pompilio et al. 2008). Also, those authors found a strong relationship between the extent of initial adhesion of Stenotrophomonas maltophilia to PS surfaces and biofilm formation.

In conclusion, controlling and preventing the adverse impact of the bacterial deposition on the aquatic environment needs an in-depth understanding about the mechanisms regulating this process. The XDLVO theory has been used extensively to describe the deposition of bacteria in many current researches. However, physicochemical approaches based on the XDLVO theory were inappropriate for modelling adhesion of the tested drinking water bacteria to PS. The adhesion results suggest that mechanisms other than physicochemical surface properties may play a determinant role on bacterial adherence ability. Bacteria themselves produce extracellular molecules with sufficient surface activity to play a role in the bacterial adhesion process. However, the adhesion step does not provide conclusive information on the formation of mature biofilms. Adhesion ability was only correlated when comparing the results of the $24 \mathrm{~h}$ biofilms. Given time, all the bacteria had the ability to form biofilms even if considered non-adherent. A. calcoaceticus, Methylobacterium sp. and M. mucogenicum were classified as weakly adherent to PS and formed large biofilm amounts. The remaining bacteria were non-adherent, however, had the ability to form biofilms. This identification of the main bacteria forming more complex biofilms (A. calcoaceticus, Methylobacterium sp. and M. mucogenicum), probably more resistant to disinfection, due to their high biomass amount, may provide new information necessary for improving water quality for the consumers. Furthermore, these biofilms can act as a harbour and/ or substrate for other microorganisms less prone to biofilm formation, increasing the probability of pathogen survival and further dissemination in the DWDS.

Acknowledgments The authors acknowledge the financial support provided by the Portuguese Foundation for Science and Technology (SFRH/BD/31661/2006_Lúcia C. Simões).

\section{References}

Absolom DR, Lamberti FV, Policova Z, Zing W, van Oss CJ, Neumann AW (1983) Surface thermodynamics of bacterial adhesion. Appl Environ Microbiol 46:90-97 
Akesso L, Pettitt ME, Callow JA, Callow ME, Stallard J, Teer D, Liu C, Wang S, Zhao Q, D‘Souza F, Willemsen PR, Donelly GT, Kocijan A, Jenko M, Jones LA, Guinaldo PC (2009) The potential of nano-structured silicon oxide type coatings deposited by PACVD for control of aquatic biofouling. Biofouling 25:55-67

An YH, Friedman RJ (1998) Concise review of mechanisms of bacterial adhesion to biomaterial surfaces. J Biomed Mater Res B 43:338-348

Andersson S, Rajarao GK, Land CJ, Dalhammar G (2008) Biofilm formation and interactions of bacterial strains found in wastewater treatment systems. FEMS Microbiol Lett 283:83-90

Azeredo J, Visser J, Oliveira R (1999) Exopolymers in bacterial adhesion: interpretation in terms of DLVO and XDLVO theories. Colloid Surf B 14:141-148

Bakker DP, Postmus BR, Busscher HJ, van der Mei HC (2004) Bacterial strains from different niches can exhibit different patterns of adhesion to substrata. Appl Environ Microbiol 70:3758-3760

Barton AJ, Sagers RD, Pitt WG (1996) Measurement of bacterial growth rates on polymers. J Biomed Mater Res A $32: 271-278$

Bauman WJ, Nocker A, Jones WL, Camper AK (2009) Retention of a model pathogen in a porous media biofilm. Biofouling 25:229-240

Bennett SM, Finlay JA, Gunari N, Wells DD, Meyer AE, Walker GC, Callow ME, Callow JA, Bright FV, Detty MR (2010) The role of surface energy and water wettability in aminoalkyl/fluorocarbon/hydrocarbon-modified xerogel surfaces in the control of marine biofouling. Biofouling 26:235-246

Bifulco JM, James T, Shirey J, Bissonnette GK (1989) Detection of Acinetobacter spp. in rural drinking water supplies. Appl Environ Microbiol 55:2214-2219

Bos R, Van der Mei HC, Busscher HJ (1999) Physicochemistry of initial microbial adhesive interactions-its mechanisms and methods for study. FEMS Microbiol Rev 23:179-230

Bryers JD, Ratner JP (2004) Bioinspired implant materials befuddle bacteria. ASM News 70:232-237

Busscher HJ, Van der Mei HC (1997) Physico-chemical interactions in initial microbial adhesion and relevance for biofilm formation. Adv Dent Res 11:24-32

Busscher HJ, Weerkamp AH, van der Mei HC, Pelt AWJ, de Jong HP, Arends J (1984) Measurements of the surface free energy of bacterial cell surfaces and its relevance for adhesion. Appl Environ Microbiol 48:980-983

Busscher HJ, Bos R, Van der Mei HC (1995) Initial microbial adhesion is a determinant for the strength of biofilm adhesion. FEMS Microbiol Lett 128:229-234

Camper AK (2004) Involvement of humic substances in regrowth. Int J Food Microbiol 92:355-364

Chae MS, Schraft H, Hansen LT, Mackereth R (2006) Effects of physicochemical surface characteristics of Listeria monocytogenes strains on attachment to glass. Food Microbiol 23:250-259

Conway B-A, Venu DV, Speert DP (2002) Biofilm formation and acyl homoserine lactone production in the Burkolderia cepacia complex. J Bacteriol 184:5678-5685

Cotter JJ, O'Gara JP, Casey E (2009) Rapid deplection of dissolved oxygen in 96-well microtiter plate Staphylococcus epidermidis biofilm assays promotes biofilm development and is influenced by inoculum cell concentration. Biotechnol Bioeng 103:1042-1047

Djordjevic D, Wiedmann M, McLandsborough LA (2002) Microtiter plate assay for assessment of Listeria monocytogenes biofilm formation. Appl Environ Microbiol 68:2950-2958

Dobretsov S, Teplitski M, Paul V (2009) Mini-review: quorum-sensing in the marine environment and its relationship to biofouling. Biofouling 25:413-427

Donlan RM (2002) Biofilms: microbial life on surfaces. Emerg Infect Dis 8:881-890

Doyle RJ (2000) Contribution of the hydrophobic effect to microbial adhesion. Microbes Infect 2:391-400

Dufrene YF, Vermeiren H, Van der Leyden J, Rouxhet PG (1996) Direct evidence for the involvement of extracellular proteins in the adhesion of Azospirillum brasilense. Microbiology 142:855-865

Emtiazi F, Schwartz T, Marten SM, Krolla-Sidenstein P, Obst $\mathrm{U}$ (2004) Investigation of natural biofilms formed during the production of drinking water from surface water embankment filtration. Water Res 38:1197-1206

Flint SH, Brooks JD, Bremer PJ (1997) The influence of cell surface properties of thermophilic streptococci on attachment to stainless steel. J Appl Microbiol 83:508-517

Fox P, Suidan MT, Bandy JT (1990) A comparison of media types in acetate fed expanded-bed anaerobic reactors. Water Res 24:827-835

Genzer J, Efimenko K (2006) Recent developments in superhydrophobic surfaces and their relevance to marine fouling: a review. Biofouling 22:339-360

Gilbert P, Allison DG, McBain AJ (2002) Biofilms in vitro and in vivo: do singular mechanisms imply cross-resistance? J Appl Microbiol 92:98S-110S

Gottenbos B, van der Mei HC, Busscher HJ, Grijpma DW, Feijnen J (1999) Initial adhesion and surface growth of Pseudomonas aeruginosa on negatively and positively charged poly(methacrylates). J Mater Sci 10:853-855

Holland NB, Qiu YX, Ruegsegger M, Marchant RE (1998) Biomimetic engineering of non-adhesive glycocalyx-like surfaces using oligosaccharide surfactant polymers. Nature 392:799-801

Hunter RJ (1981) Zeta potential in colloid science, principles and applications. Academic Press, London

Janczuk B, Chibowski E, Bruque JM, Kerkeb ML, GonzalezCaballero FJ (1993) On the consistency of surface free energy components as calculated from contact angle of different liquids: an application to the cholesterol surface. J Colloid Interface Sci 159:421-428

Johansen TB, Agdestein A, Olsen I, Nilsen SF, Holstad G, Djønne B (2009) Biofilm formation by Mycobacterium avium isolates originating from humans, swine and birds. BMC Microbiol 9:159

Kogure K, Ikemoto E, Morisaki H (1998) Attachment of Vibrio alginolyticus to glass surfaces is dependent on swimming speed. J Bacteriol 180:932-937

LeChevalier MW, Babcock TM, Lee RG (1987) Examination and characterization of distribution systems biofilms. Appl Environ Microbiol 53:2714-2724

Li B, Logan BE (2004) Bacterial adhesion to glass and metaloxide surfaces. Colloid Surf B 36:81-90 
Liu Y, Zhang W, Sileika T, Warta R, Cianciotto NP, Packman A (2009) Role of bacterial adhesion in the microbial ecology of biofilms in cooling tower systems. Biofouling 25:241-253

Meinders H, van der Mei HC, Busscher HJ (1995) Deposition efficiency and reversibility of bacterial adhesion under flow. J Colloid Interface Sci 176:329-341

Morisaki H, Nagai S, Ohshima H, Ikemoto E, Kogure K (1999) The effect of motility and cell-surface polymers on bacterial attachment. Microbiology 145:2797-2802

Niquette P, Servais P, Svoir R (2000) Impacts of pipe materials on densities of fixed bacterial biomass in a drinking water distribution system. Water Res 34:1952-1956

Oliveira K, Oliveira T, Teixeira P, Azeredo J, Oliveira R (2007) Adhesion of Salmonella enteritidis to stainless steel surfaces. Braz J Microbiol 38:318-323

Pavithra D, Doble M (2008) Biofilm formation, bacterial adhesion and host response on polymeric implants-issues and prevention. Biomed Mater 3:034003

Pavlov D, de Wet CME, Grabow WOK, Ehlers MM (2004) Potentially pathogenic features of heterotrophic plate count bacteria isolated from treated and untreated drinking water. Int J Food Microbiol 92:275-287

Percival SL, Walker JT (1999) Potable water and biofilms: a review of the public health implications. Biofouling 42:99-115

Petrozzi S, Kut OM, Dunn IJ (1993) Protection of biofilms against toxic shocks by the adsorption and desorption capacity of carriers in anaerobic fluidized bed reactors. Bioprocess Biosyst Eng 9:47-59

Pompilio A, Piccolomini R, Picciani C, D‘Antonio D, Savini V, Bonaventura GD (2008) Factors associated with adherence to and biofilm formation on polystyrene by Stenotrophomonas maltophila: the role of cell surface hydrophobicity and motility. FEMS Microbiol Lett 287:41-47

Pratt LA, Kolter R (1998) Genetic analysis of Escherichia coli biofilm formation: roles of flagella, motility, chemotaxis and type I pili. Mol Microbiol 30:285-293

Quirynen M, Van der Mei HC, Bollen CML, Schotte A, Marechal M, Doornbusch GI, Naert I, Busscher HJ, Van Steenberghe D (1993) An in vivo study of the influence of the surface roughness of implants on the microbiology of supra- and subgingival plaque. J Dent Res 72:1304-1309

Regan JM, Harrington GW, Baribeau H, Leon RD, Noguera DR (2003) Diversity of nitrifying bacteria in full-scall chloraminated distribution systems. Water Res 37:197205

Rickard AH, McBain AJ, Ledder RG, Handley PS, Gilbert P (2003) Coaggregation between freshwater bacteria within biofilm and planktonic communities. FEMS Microbiol Lett 220:133-140

Rickard AH, McBain AJ, Stead AT, Gilbert P (2004) Shear rate moderates community diversity in freshwater biofilms. Appl Environ Microbiol 70:7426-7435

Rijnaarts HHM, Norde W, Lyklema J, Zehnder AJB (1999) DLVO and steric contributions to bacterial deposition in media of different ionic strengths. J Colloid Interface Sci 14:179-195

Rodrigues DF, Elimelech M (2009) Role of type I fimbriae and mannose in the development of Escherichia coli K12 biofilms: from initial cell adhesion to biofilm formation. Biofouling 25:401-411

Roosjen A, Busscher HJ, Norde W, van der Mei HC (2006) Bacterial factors influencing adhesion of Pseudomonas aeruginosa strains to a poly(ethylene oxide) brush. Microbiology 152:2673-2682

Rusin PA, Rose JB, Haas CN, Gerba CP (1997) Risk assessment of opportunistic bacterial pathogens in drinking water. Rev Environ Contam Toxicol 152:57-83

Rutter PR, Vincent B (1984) Physicochemical interactions of the substratum, microorganisms and the fluid phase. In: Marshall KC (ed) Microbial adhesion and aggregation. Springer, Berlin

Sauer K, Camper AK (2001) Characterization of phenotypic changes in Pseudomonas putida in response to surfaceassociated growth. J Bacteriol 183:6579-6589

Silva MEZ, Filho IC, Endo HE, Nakamura CV, Ueda-Nakamura T, Filho BPD (2008) Characterisation of potential virulence markers in Pseudomonas aeruginosa isolated from drinking water. Antonie van Leeuwenhoek 93:323-334

Simões LC, Azevedo N, Pacheco A, Keevil CW, Vieira MJ (2006) Drinking water biofilm assessment of total and culturable bacteria under different operating conditions. Biofouling 22:91-99

Simões LC, Simões M, Oliveira R, Vieira M (2007a) Potential of the adhesion of bacteria isolated from drinking water to materials. J Basic Microbiol 47:174-183

Simões LC, Simões M, Vieira MJ (2007b) Biofilm interactions between distinct bacterial genera isolated from drinking water. Appl Environ Microbiol 73:6192-6200

Simões LC, Simões M, Vieira MJ (2008a) Intergeneric coaggregation among drinking water bacteria: evidence of a role for Acinetobacter calcoaceticus as a bridging bacterium. Appl Environ Microbiol 74:1259-1263

Simões M, Simões LC, Pereira MO, Vieira MJ (2008b) Antagonism between Bacillus cereus and Pseudomonas fluorescens in planktonic systems and in biofilms. Biofouling 24:339-349

Simões M, Bennett RN, Rosa EA (2009) Understanding antimicrobial activities of phytochemicals against multidrug resistant bacteria and biofilms. Nat Prod Rep 26:746-757

Sinde E, Carballo J (2000) Attachment of Salmonella spp. and Listeria monocytogenes to stainless steel, rubber and polytetrafluorethylene: the influence of free energy and the effect of commercial sanitizers. Food Microbiol 17:439-447

Sousa C, Teixeira P, Oliveira R (2009) Influence of surface properties on the adhesion of Staphylococcus epidermidis to acrylic and silicone. Int $\mathrm{J}$ Biomater. doi: $10.1155 / 2009 / 718017$

Stelma GN Jr, Lye DJ, Smith BG, Messer JW, Payment P (2004) Rare occurrence of heterotrophic bacteria with pathogenic potential in potable water. Int $\mathrm{J}$ Food Microbiol 92:249-254

Stepanović S, Vuković D, Davić I, Savić B, Ŝvabić-Vlahović M (2000) A modified microtiter-plate test for quantification of staphylococcal biofilm formation. J Microbiol Methods 40:175-179

Szewzyk U, Szewzyk R, Manz W, Schleifer KH (2000) Microbiological safety of drinking water. Annu Rev Microbiol 54:81-127 
Thomas WE, Trintchina E, Forero M, Vogel V, Sokurenko EV (2002) Bacterial adhesion to target cells enhanced by shear force. Cell 109:913-923

van Hoogmoed CG, Kuijl-Booij M, Van der Mei HC, Busscher HJ (2000) Inhibition of Streptococcus mutans NS adhesion to glass with and without a salivary conditioning film by biosurfactant-releasing Streptococcus mitis strains. Appl Environ Microbiol 66:659-663

van Loosdrecht MC, Lyklema J, Norde W, Zehnder AJB (1988) Hydrophobic and electrostatic parameters in bacterial adhesion. Microb Ecol 17:1-15

van Loosdrecht MC, Lyklema J, Norde W, Zehnder AJB (1990) Influence of interfaces on microbial activity. Microbiol Mol Biol Rev 54:75-87

van Oss CJ (1989) Energetics of cell-cell and cell-biopolymer interactions. Cell Biochem Biophys 14:1-16

van Oss CJ (1994) Interfacial forces in aqueous media. Marcell Dekker, New York

van Oss CJ (1995) Hydrophobicity of biosurfaces-origin, quantitative determination and interaction energies. Colloid Surf B 5:91-110

van Oss CJ (1997) Hydrophobicity and hydrophilicity of biosurfaces. Curr Opin Colloid Interface Sci 2:503-512

van Oss CJ, Good RJ, Chaudhury MK (1986) The role of Van der Waals forces and hydrogen bonds in hydrophobic interactions between biopolymers and low energy surfaces. J Colloid Interface Sci 111:378-390

van Oss CJ, Chaudhury MK, Good RJ (1987) Monopolar surfaces. Adv Colloid Interface Sci 28:35-64

van Oss CJ, Good RJ, Chaudhury MK (1988) Additive and nonadditive surface tension components and the interpretation of contact angles. Langmuir 4:884-891

van Oss CJ, Ju L, Chaudhury MK, Good RJ (1989) Estimation of the polar parameters of the surface tension of liquids by contact angle measurements on gels. J Colloid Interface Sci 128:313-319

Walker SL, Redman JA, Elimelech M (2004) Role of cell surface lipopolysaccharides in Escherichia coli K12 adhesion and transport. Langmuir 20:7736-7746

Walker SL, Redman JA, Elimelech M (2005) Influence of growth phase on bacterial deposition: interaction mechanisms in packed-bed column and radial stagnation point flow systems. Environ Sci Technol 39:64056411

Webster DC, Chisholm BJ, Stafslien SJ (2007) Mini-review: combinatorial approaches for the design of novel coating systems. Biofouling 23:179-192

Zanetti F, De Luca G, Stampi S (2000) Recovery of Burkolderia pseudomallei and B. cepacia from drinking water. Int J Food Microbiol 59:67-72 